\title{
Het opslaan van een oog : tijdelijkheid en ongelijktijdigheid in hedendaagse kunst
}

Citation for published version (APA):

van de Vall, R. (2010). Het opslaan van een oog : tijdelijkheid en ongelijktijdigheid in hedendaagse kunst. Maastricht University. https://doi.org/10.26481/spe.20100507rv

Document status and date:

Published: 07/05/2010

DOI:

10.26481/spe.20100507rv

Document Version:

Publisher's PDF, also known as Version of record

\section{Please check the document version of this publication:}

- A submitted manuscript is the version of the article upon submission and before peer-review. There can be important differences between the submitted version and the official published version of record.

People interested in the research are advised to contact the author for the final version of the publication, or visit the DOI to the publisher's website.

- The final author version and the galley proof are versions of the publication after peer review.

- The final published version features the final layout of the paper including the volume, issue and page numbers.

Link to publication

\footnotetext{
General rights rights.

- You may freely distribute the URL identifying the publication in the public portal. please follow below link for the End User Agreement:

www.umlib.nl/taverne-license

Take down policy

If you believe that this document breaches copyright please contact us at:

repository@maastrichtuniversity.nl

providing details and we will investigate your claim.
}

Copyright and moral rights for the publications made accessible in the public portal are retained by the authors and/or other copyright owners and it is a condition of accessing publications that users recognise and abide by the legal requirements associated with these

- Users may download and print one copy of any publication from the public portal for the purpose of private study or research.

- You may not further distribute the material or use it for any profit-making activity or commercial gain

If the publication is distributed under the terms of Article $25 \mathrm{fa}$ of the Dutch Copyright Act, indicated by the "Taverne" license above, 
Het opslaan van een oog.

Tijdelijkheid en ongelijktijdigheid in hedendaagse kunst

\title{
Rede
}

Uitgesproken bij de aanvaarding van het ambt van bijzonder hoogleraar Kunst en Media aan de Faculteit der Cultuur- en Maatschappijwetenschappen van de Universiteit Maastricht

op vrijdag 7 mei 2010

door dr. Renée van de Vall

\author{
... Zelfs het geringste \\ opslaan van een oog haalt onherstelbaar \\ overhoop en brengt teweeg en brengt teweeg. \\ Judith Hertzberg, De visser. In: Botshol.
}

Mijnheer de rector magnificus, geachte aanwezigen,

Tijdens deze inaugurele rede wil ik u uitnodigen mee terug te gaan in de tijd en met mij een tentoonstelling te bezoeken die ongeveer twee jaar geleden haar deuren opende. ${ }^{1}$ We zijn in de zomer van het jaar 2008. Tegen het decor van de Italiaanse Dolomieten, om precies te zijn in het vroegere Zuid-Tirol - nu de autonome regio Trentino-Zuid-Tirol - vindt de 7e Manifesta Biënnale plaats. De Manifesta is een tweejaarlijkse tentoonstelling voor hedendaagse kunst die telkens een nieuwe locatie in Europa opzoekt. De eerste Manifesta werd in 1996 Rotterdam gehouden; daarna waren er onder meer tentoonstellingen in Ljubljana en San Sebastian. Vaak worden locaties met een beladen politieke geschiedenis opgezocht. Zo zou de 6e Manifesta in Nicosia op Cyprus plaatsvinden, maar als gevolg van een politiek conflict over de precieze locatie - er zou ook in het Turkse deel van de stad worden geëxposeerd ging de hele tentoonstelling niet door. Ook de regio Trentino-Zuid Tirol heeft een roerig verleden. Tot 1919 hoorde Zuid-Tirol bij Oostenrijk; daarna werd het gebied door Italië geannexeerd. Mussolini doopte het vrijwel geheel Duitstalige gebied om tot Alto Adige en verbood Duitse les op scholen. Het stadje Bozen werd Bolzano. Na WO II werd het gebied officieel tweetalig, maar er bleven spanningen tussen de bevolkingsgroepen - zo waren er bijvoorbeeld terroristische aanslagen van Duitstalige separatisten. Na de toetreding van Italië bij de EU in 1995 en verdergaande autonomie voor de twee provincies Trente en Bozen-Zuidtirol verminderden de spanningen.

Deze zevende Manifesta vindt niet plaats in één stad maar is verspreid over vier plaatsen in de regio. Verschillende teams van curatoren hebben op verschillende locaties exposities ingericht en Bolzano is een daarvan. In een oude aluminiumfabriek, in de jaren '30 onder Mussolini gebouwd om Italiaanse arbeiders

\footnotetext{
${ }^{1}$ Voor afbeeldingen van de besproken kunstwerken zie de website van de tentoonstelling: http://www.manifesta7.it/artists/. Twee korte filmimpressies van The Rest of Now zijn te vinden op http://vernissage.tv/blog/2008/08/06/manifesta-7-the-rest-of-now-bolzanobozen-italy-part-12/ en http://vernissage.tv/blog/2008/08/08/manifesta-7-the-rest-of-now-bolzanobozen-italy-part-22/
} 
aan te trekken, heeft Indiase kunstenaarsgroep Raqs Media Collective een tentoonstelling gemaakt met als titel The Rest of Now. De locatie leverde het motief voor de tentoonstelling. Aluminium wordt opgevoerd als symbool van het Futuristische geloof in vooruitgang en snelheid - het materiaal voor vliegtuigen, bommen en niet te vergeten koffiepercolators. De tentoonstelling roept het beeld op van de vooruitgang als steeds doorgaand en zich ook steeds verplaatsend bewerkingsproces waarin een waardevolle stof uit een grondstof wordt gewonnen, maar dat steeds ook restanten achterlaat. Zoals de catalogus formuleert:

Let us rest for now, between an odd and an even beat, and consider what remains from a century devoted to the breathless pursuit of tomorrow's promised riches. (Raqs Media Collective 2008, p. 51)

De leidende metafoor is die van extract en residu:

The extraction of value from any material, place thing or person, involves a process of refinement. During this process, the object in question will undergo a change in state, separating into at least two substances: an extract and a residue. (Ibid., p. 53)

De fabriek zelf, in onbruik geraakt omdat de productie zich naar elders heeft begeven, is "a monument to its own residue" (Ibid., p. 51).

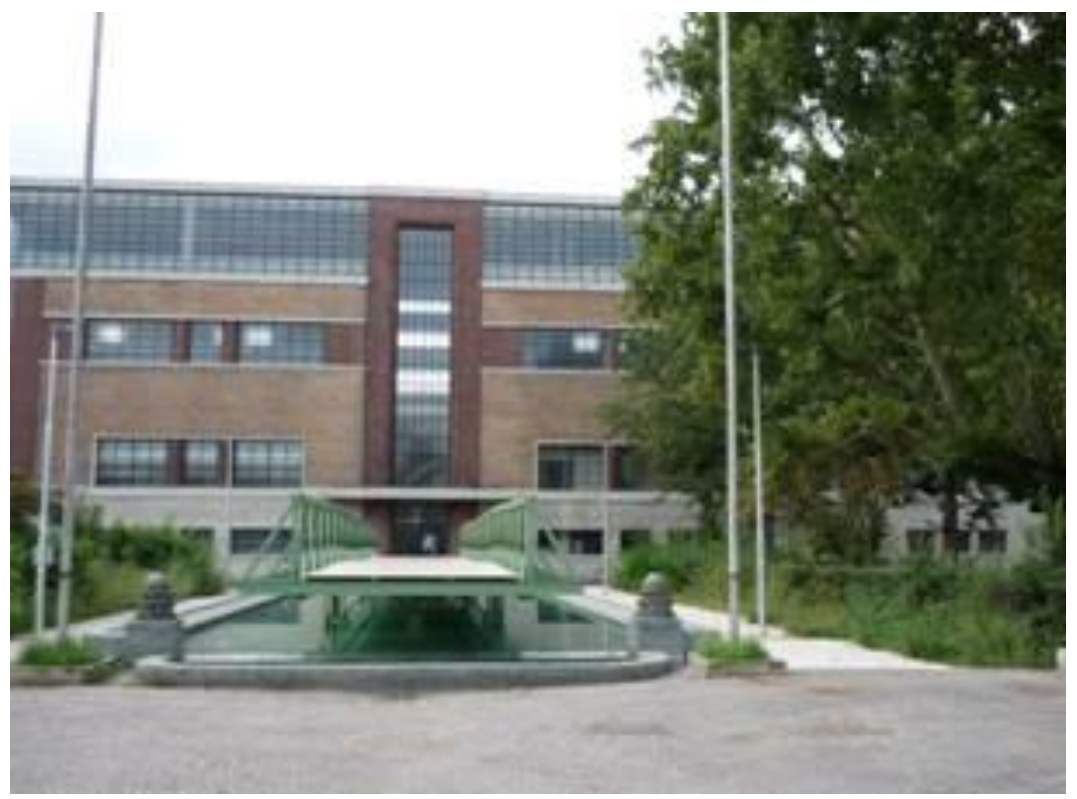

Ex-Alumix Bolzano. Foto: R. van de Vall

Een aantal kunstwerken hebben inderdaad aluminium als onderwerp, zoals Graham Harwood's Aluminium, een videowerk naar aanleiding van een futuristische graphic novel, of Sanjay Kak's A Shrine To the Future: Memory of a Hill, een hindoeïstische schrijn gewijd aan een voor de bauxietwinning afgegraven heuvel in Orissa. Een zijzaal waarin iedere week een ander project werd vertoond, stond toen ik er kwam vol espressopotjes. Andere installaties gingen meer in het algemeen over het gegeven extract en residu. Een in de fabriek achtergelaten telefooncentrale was de drager 
geworden voor een geluidskunstwerk gemaakt van telefoongesprekken uit Kongo, ter gedachtenis van de doden van de 'Coltan wars' - van het daar gewonnen tantalum wordt een component van mobiele telefoons gemaakt (Graham Harwood, Richard Wright en Matsuko Yokokoji, Tantalum Memorial-Residue). Spraakmakend was Teresa Margolles' Sudor y Miedo, een lege ruimte besproeid met afvalwater gebruikt in een mortuarium. Zilvinas Kempinas Skylight Tower speelde met de lichtval van het daklicht met behulp van afgespoelde videotapes.

De besprekingen van de tentoonstelling zijn gemengd. Waar de ene criticus de tentoonstelling verrassend, stimulerend en uitdagend vindt (Gillian Sneed in NYArts) of levendig en evocatief (Cathryn Drake in Artforum), klagen andere over onsamenhangendheid (Axel Lapp in Axis), vage jaren '90 retoriek en intellectualisme (Allessandro Rabottini in Modern Painters), of 'curatorial mannerism' (Shumon Basar in Artreview). Sandra Smallenburg in NRC Handelsblad prijst een enkel werk, is onder de indruk van de locatie, maar zegt dat de kunstwerken verdrinken in de monumentale architectuur en dat er "teveel politiek correct geneuzel, teveel vergezochte conceptuele ingrepen" te zien zijn (Smallenburg 2008, p. 9). In het blad Design is Nick Currie positiever, al lijkt ook op hem de locatie meer indruk gemaakt te hebben dan de kunst. In een paar zinnen geeft hij een treffende samenvatting van de expositie:

Inside, the light and space of a structure, which feels like Rome's Termini Station crossed with a cathedral, make the spirit soar. The curators - Raqs Media Collective from New Delhi - haven't let a good metaphor escape them; aluminum smelting has become the key to their curation, raising apt images of extraction and residue. What's been extracted from Ex-Alumix isn't just aluminum but labor itself: the labor that once separated metal from rough ore. What remains - what's the residue? - when work is extracted from a factory? A bunch of ghosts: electronic images, mostly, of people hard at work in other parts of the world. Outsourcing as art. (Currie 2008)

Carolina Corbetta klaagt daarentegen in Domus dat de tentoonstelling, ondanks de locatie, niet coherent is:

At the ex-Alumix in Bolzano, the three curators of the Raqs Media Collective had an open space at their disposal, a great big room that allows for visual connection between the various pieces. Yet, while persevering with the concept of residue, both through the signs of the building and in the iconography of many pieces, they haven't managed to create a subtext that pulls the whole thing together. (Corbetta 2008, p. 130)

\section{Kunst als Gestalt-shift}

De critici hadden niet helemaal ongelijk. De locatie was indrukwekkend - niet voor niets vergeleken veel commentaren het gebouw met Tate Modern, ook zo'n monument van industriële architectuur. De Alumix fabriek is een voorbeeld van de onder het fascisme populaire architettura razionale, de Italiaanse variant van het Nieuwe Bouwen. In de immense ruimte van de fabriekshal leken veel van de installaties te krimpen, al wisten sommige de ruimte toch ook op een prachtige manier te benutten. Er was inderdaad weinig visuele ruimtelijke samenhang tussen de 
opgestelde werken. Omdat veel van de installaties sterk conceptueel van karakter waren, was de algehele sfeer van de tentoonstelling nogal intellectueel en afstandelijk, op het steriele af.

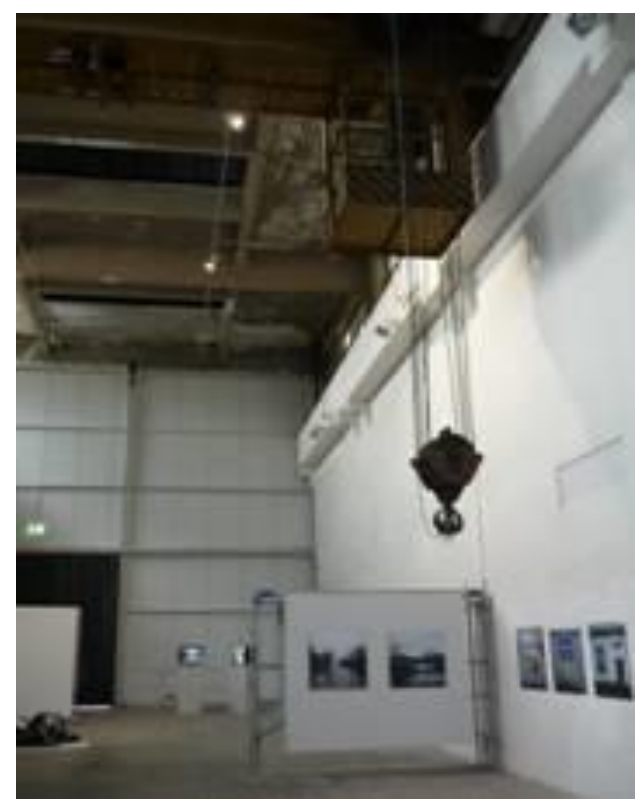

Interieur Ex Alumix. Foto R. van de Vall

Helemaal verrassend was dat niet. Raqs Media Collective is een interdisciplinair werkende groep, waarvan de leden, Jeebesh Bagchi, Monica Narula \& Shuddhabrata Sengupta, zich niet alleen als kunstenaars, maar evenzeer als media-practitioners, curatoren, onderzoekers en culturele activisten beschouwen. Hun werk ligt op het snijvlak van kunst en onderzoek, zoals veel kritische hedendaagse kunst, en zij zijn bijvoorbeeld ook medeoprichters van het in Nederland (en zeker in India) inmiddels vrij bekende onderzoekscentrum Sarai.

De vraag is altijd of kunst die zozeer de raakvlakken met intellectueel onderzoek opzoekt ook in artistiek opzicht nog boeiend en overtuigend blijft en niet verzandt in een soort amateur journalistiek of tweedehands filosofie. Ik denk dat daar geen eensluidend antwoord op te geven is en dat je van geval tot geval moet beoordelen. Mijn criterium is of een tentoonstelling of kunstwerk meer doet dan een concept illustreren, bijvoorbeeld doordat het vragen oproept of ervaringen in gang zet die je de wereld om je heen net iets anders laten zien: een kleinere of grotere Gestalt-shift teweeg brengt die je nog lang stof tot nadenken geeft. Dat criterium is in feite geënt op Immanuel Kants formulering van de esthetische idee:

... onder een esthetische idee versta $\mathrm{ik}$ een voorstelling van de verbeeldingskracht die veel te denken geeft, zonder dat er een bepaalde gedachte, d.w.z. een begrip, volledig aan kan beantwoorden; een voorstelling dus die geen enkele taal volledig kan bereiken en begrijpelijk kan maken. (Kant 2009, p. 209)

Net als filosofie, wetenschap of journalistiek probeert kunst iets te begrijpen van de wereld, van onze relaties tot die wereld, tot andere mensen, tot onszelf. Kunstwerken hebben betekenis, niet alleen doordat ze letterlijk iets zeggen, al doen ze dat vaak, 
maar ook en vooral doordat ze ervaringen ensceneren. Dat ensceneren wil zeggen dat kunstwerken een omgeving creëren waarin je uitgenodigd wordt om bepaalde ervaringen op te doen - en die doe je op door iets te doen, door te kijken, te luisteren, te lopen, aan te raken, te lezen, soms een muis of controller te bewegen. Kunstwerken zijn performatief in de zin dat ze iets teweegbrengen: en ze brengen teweeg door jou iets te laten doen, al is dat zo mimimaal als het opslaan van een oog. In dat doen kan het gebeuren dat er iets verschuift in hoe je de wereld beleeft of voorstelt of begrijpt bijvoorbeeld doordat de ervaring je voor een raadsel stelt. Wanneer die Gestalt-shift, door iets te veranderen aan de basale patronen die onze ervaring vormgeven, iets over die patronen duidelijk maakt, raakt kunst niet alleen aan filosofie, maar voegt daar ook iets aan toe (Van de Vall 2008).

\section{The Dialogue Remains}

Dat ik de tentoonstelling uiteindelijk inderdaad als een soort Gestalt-shift ging ervaren, had te maken met een installatie die voor mij de toon van het geheel ging bepalen omdat het precies de samenhang in gang zette die sommige critici misten. De titel van de installatie was The Dialogue Remains. In een nis waren twee videofilms te zien: de ene film werd in groot formaat op de achterwand van de nis geprojecteerd en de tweede op een LCD scherm op de voorgrond. De catalogus van de tentoonstelling vertelt in het kort het verhaal. De scènes spelen zich af op en bouwterrein in Kolkata, waar een projectontwikkelaar gigantische woontorens bouwt. De grond was voorheen in gebruik van de firma Jay Engineering Works, producent van onder andere naaimachines. Nadat de firma in 2004 was verkocht, werden de arbeiders zonder of met heel weinig vergoeding uit hun huizen gezet. Een van de werknemers weigerde te vertrekken. Deze Shambu Prasad Singh begon een rechtzaak en kon, althans voorlopig, in zijn huis blijven. De filmmaakster Ranu Ghosh volgde de ontwikkelingen rond de voormalige fabriek sinds 2004. Zij mocht het bouwterrein niet betreden en ging met Shambu Prasad Singh samenwerken, die er nog steeds woonde. Ze vroeg hem zijn huis en de werkzaamheden op het terrein van binnen uit filmen. De beelden die we op de achterwand zien zijn door hem geschoten, de beelden op het LCD scherm zijn van Ranu Ghosh zelf.

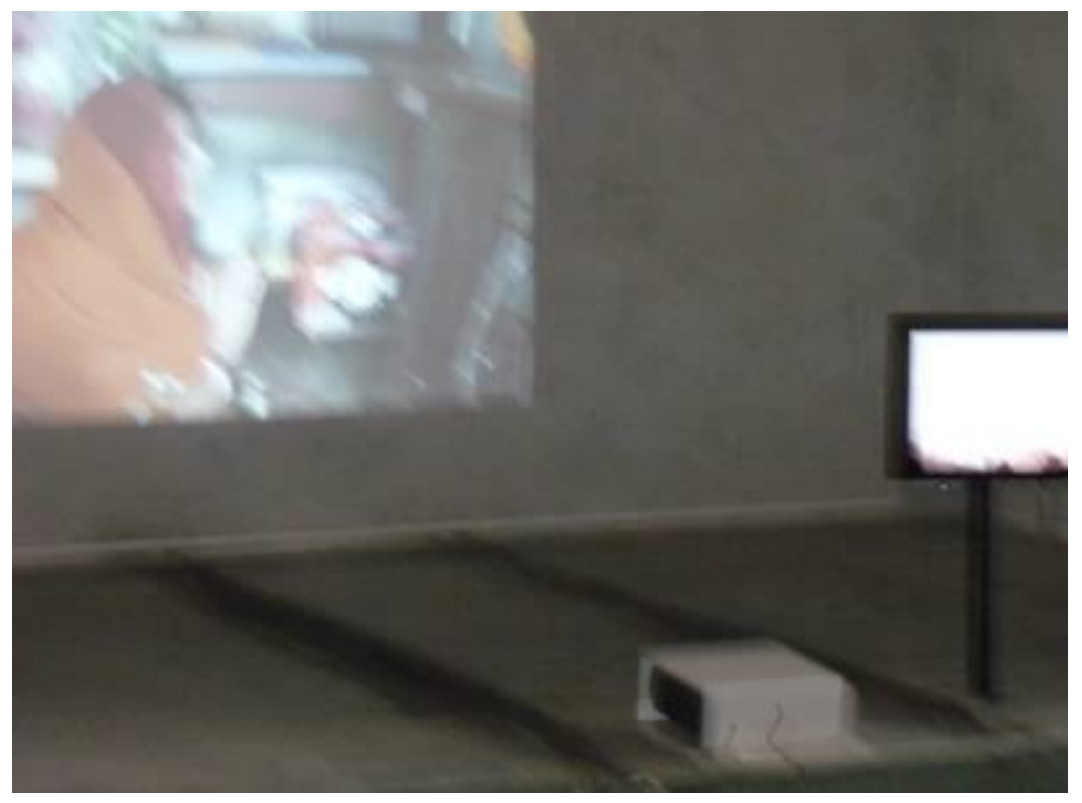


Er is een verschil in inhoud en stijl van de twee videofilms. De video op de achterwand toont van vrij dichtbij de bedrijvigheid op het bouwterrein, de bezigheden van de bewoners in het huis, met name de kleine rituelen rond de naaimachine - een Ushi naaimachine, geproduceerd door de fabriek die nu afgebroken wordt en een household name in India zoals bij ons Singer dat was (zo vertelden mij mijn Indiase gastvrouwen later). Je hoort bouwlawaai, huisgeluiden, zingen. De video op het LCD scherm is geluidloos. Met een soms tergende traagheid beweegt de camera, van grote afstand, omhoog, omlaag, naar links of rechts; ze volgt de lijnen van de immense flats met hun holle ramen, de lijnen van de kranen aan het werk, staat soms een tijd stil. Af en toe verschijnt er een tekst op het scherm, een bespiegeling over de stad, de tijd of de herinnering van de maakster over de kleren die haar moeder vroeger naaide op haar Ushi naaimachine. De eerste video is een directe, commentaarloze registratie van wat er gebeurt; de tweede is meer contemplatief, zowel in woord als in beeld.

Ik heb lang op de tentoonstelling rondgelopen, maar steeds keerde ik terug naar deze nis. De volgende dag ben ik nog een keer teruggegaan op de opnames te maken die ik u nu laat zien. Ik denk dat deze installatie net dat deed wat veel van de andere werken misten: me in een ervaring zuigen. Terugkijkend, in een poging dat effect te analyseren, kwam ik er op uit dat het kwam door de manier waarop de video's speelden met de tijd. Samen brengen ze twee tijdsschalen met elkaar in gesprek: het kortstondige verloop van de dagelijkse bedrijvigheid werd gecontrasteerd met een meer uitgerekte tijdsschaal, de tijdspanne van laten we zeggen, een generatie, een mensenleven.

In de combinatie van die twee video's gebeurt er iets bijzonders. Dat bijzondere is dat de wisselwerking tussen de twee tijdschalen een derde tijdsschaal creëert, een tijd die noch aan de ene noch aan de andere video kan worden afgelezen. De enige plek waar die tijd waarneembaar is, is in de ervaring van de toeschouwer wiens aandacht zich verdeelt over de twee video's met hun uiteenlopende tempo's en ritmiek. Noem het een tussentijd, een tijd behorend aan de installatie als geheel, aan de ruimte die wordt gevormd door de beelden, de wanden en vloeren van de nis waarin de installatie staat opgesteld, en de toeschouwer.

\section{Filmervaring}

Hoe breng je zo'n ervaring in kaart? Ervaringen zijn uiteraard subjectief, maar dat wil niet zeggen dat je er niet in het algemeen iets over zou kunnen zeggen. De Amerikaanse filmtheoretica Vivian Sobchack heeft veel geschreven over de structuur van wat zij de 'filmervaring' noemt (Sobchack 1992; 2004). Zij analyseert die vanuit de fenomenologie van Merleau-Ponty en de post-fenomenologische techniekfilosofie van Don Ihde. Die filmervaring ontstaat, zegt zij, uit de wisselwerking van twee blikken: de blik van de camera en de blik van de toeschouwer. Die twee vallen niet samen: de blik van de camera is niet blik van de toeschouwer en de blik van de toeschouwer valt niet samen met die van de camera. Beide hebben een eigen vorm van lichamelijkheid, die van de toeschouwer wordt bepaald door diens fysiologie, de blik van de camera door de technologie. 
Waarneming is altijd dynamisch proces waarin je al dan niet bewust keuzes maakt in waar je naar kijkt en hoe je kijkt. Waarneming is nauw verbonden met lichamelijke en geestelijke beweging: iedereen heeft wel eens meegemaakt hoezeer een omgeving van gedaante kan veranderen als je er niet doorheen fietst op weg naar een afspraak maar er wandelt op een vrije middag. Wat je opvalt en wat niet, wat 'voorgrond' is en wat 'achtergrond', is heeft alles te maken met wat op een bepaald moment belangrijk voor je is. Daarom is waarneming ook expressief: in de manier waarop je waarneemt geef je vorm aan wie je bent en hoe je je in de wereld beweegt. Film als medium nu heeft het mogelijk gemaakt om als het ware van binnenuit de waarneming van een ander mee te maken. De stroom van beelden die wij op het scherm zien geeft ons de gelegenheid om de waarneming van een ander mee te beleven, om mee te kijken met de ogen van een ander die zich door de wereld beweegt, te zien wat de ander opvalt, lang stil te staan bij het ene detail en snel voorbij te gaan aan het andere.

Maar al kijk je met die andere blik mee, je kijkt er ook tegenaan. Hoezeer die andere blik je ook meevoert, je kijkt toch altijd óók naar een scherm. Het gaat altijd om twee blikken en de blik van de camera valt nooit helemaal samen met jouw blik, al was het alleen maar omdat je je ogen dicht kan doen of je hoofd kan omdraaien. De blik van de camera loopt door een landschap, maar jij zit stil op een stoel. Die dubbelheid van de filmervaring - dat je met de blik van de camera meekijkt maar er ook tegenaan kijkt - wordt heel duidelijk in deze installatie, waarin je te maken hebt met twee films tegelijkertijd. De dubbelheid wordt nog eens verdubbeld. Elk van beide video's belichaamt een manier van kijken en vraagt je om met die blik mee te kijken; maar omdat je je niet in twee ervaringen tegelijk kunt verliezen, blijf je je bewust van je eigen lichamelijke positie ten opzichte van de beide beeldschermen die je ziet.

Juist in de uitwisseling tussen die twee blikken gebeuren interessante dingen. Sobchack heeft heel mooi geschreven over het synesthetische verschijnsel dat je soms bijna letterlijk ruikt of proeft of voelt wat er op het scherm te zien is. Je voelt natuurlijk niet echt de stof van de jurk die de heldin draagt, maar je eigen lichaam mobiliseert een veralgemeniseerde gewaarwording van tastbaarheid, wat een diffuus maar intens gevoel kan zijn dat plaatsvindt ergens in de wisselwerking tussen je lichaam en het beeld. Iets dergelijks zou ook hier aan de hand kunnen zijn, al is het niet een uitwendig zintuig dat wordt aangesproken maar eerder wat Kant de 'innere Sinn' heeft genoemd, de gewaarwording van je eigen gewaarwordingen, hier in het bijzonder een besef van trance. Je aandacht verdeelt zich, het hypnotiserende effect van de flatscreen beelden deelt zich mee aan het geheel van de installatie en wordt ook lichamelijk merkbaar in hoe je eigen waarneming voelt uitspreiden, vertragen en terugbuigen naar het fysieke hier en nu waar je staat.

\section{De performative articulatie van tijd}

Een centraal begrip in mijn onderzoek is dat van 'performatieve articulatie', waarmee ik probeer aan te geven hoe de toeschouwer van een kunstwerk in het voltrekken van de activiteit van het toeschouwen iets ontdekt. Articulatie wil zeggen dat een ervaring of impressie die eerst vormloos was, vorm en structuur krijgt. Je ziet steeds meer nuances, verschillen en overeenkomsten, contrasten en verbanden in wat zich daarvoor als een vage wolk voordeed. Om dat uit te leggen ken ik geen beter voorbeeld dan Bruno Latours beschrijving van de 'odor kit' (Latour 2004), het koffertje met flesjes vol geurtjes dat medewerkers in de parfumindustrie gebruiken 
om hun neuzen te trainen in het leren te onderscheiden van de ingrediënten van een geur. Mensen die eerst ternauwernood 'lekker' van 'stank' konden onderscheiden, leren het verschil tussen vanille, amber, muskus en jasmijn; hun voorheen vlakke geurwereld wordt veelzijdig, complex en interessant. Zowel dat koffertje, de technische bemiddeling, als het herhaaldelijke doen, de lichamelijke training, zijn daarbij onontbeerlijk. En zoals Latour aangaf, kan je in dat doen geen scheiding aanbrengen tussen subject en object: in het doen vorm je zowel nieuwe zintuigen als nieuwe zintuiglijke werelden.

Zo kan ook een kunstwerk een soort geurkoffertje worden. Het kan je leren een stukje van de wereld beter of anders te zien door nieuwe onderscheidingen maken en onverwachte verbanden te leggen. Hier is gaat het om de beleving en verbeelding van de tijd. The Dialogue Remains brengt een gelaagdheid aan in wat een geheel lijkt, onderscheidt meerdere dimensies in wat eerst een onproblematisch en betrekkelijk vormloos gegeven was. Hoe ervaar je tijd? Met die vraag loop ik weer de tentoonstelling in.

\section{Ongelijktijdigheid}

Als we op zoek zin naar een verbindende subtekst voor de tentoonstelling, zou die wel eens in de tijd kunnen liggen, al is die dan niet direct visueel gegeven. In de catalogus is tijd in elk geval een belangrijk thema.

The "rest of now" is the residue that lies at the heart of contemporaneity. It is what persists from moments of transformation, and what falls through the cracks of time. (Raqs Media Collective 2008, p. 52)

Looking out with the artists, looking out of the factory, towards the mountains, this exhibition layers, leaches and addles time. It arrests and thickens time, sows time's seeds in a garden, bores time's holes in masonry, scrapes time's dust of a wall, builds time's bridge to nowhere, measures time in terms of detritus, tells stories about the stubborn persistence of things, people and ways of life that refuse to admit that their time is over or that it hasn't yet come. (Ibid., 53)

Wat is het voor een tijd die gelaagd, geloogd en in de war gebracht kan worden? Niet een neutrale, omvattende en objectieve maat voor gebeurtenissen; eerder een complexe verzameling van bewegingen die door die gebeurtenissen worden voortgebracht. In haar intreerede voor de Haagse Hogeschool heeft Marli Huijer het begrip 'tijdsschappen' gebruikt: "temporele landschappen" die "worden gevormd door een veelheid aan op elkaar inwerkende ritmes en temporele activiteiten die met elkaar een geheel vormen" (Huijer 2008, p. 23). Tijd is complex en gelaagd omdat de manier waarop we tijd indelen en beleven gebonden is aan verschillende, soms samenlopende en soms uiteenlopende gebeurtenissen; dat zijn vaak natuurverschijnselen - het opkomen en ondergaan van de zon, de maanstanden, de seizoenen - maar ook culturele praktijken als werk- en rustdagen, religieuze en nationale rituelen, maaltijden, sportwedstrijden en televisieprogramma's. Tijd wordt bemiddeld door allerlei soorten apparaten en technieken, van de klok tot het spoorboekje, en niet in het 
minst door media: van de telegrafie en de telefoon via 'live' radio en tv naar het internet en de mobiele telefoon. Sommige aspecten van de tijd zijn lineair en onomkeerbaar, andere zijn cyclisch, sommige meet je aan verandering en andere aan herhaling, sommige zijn snel en andere langzaam.

De dynamische structuur van een tijdsschap kan vergeleken worden met een muziekpartij, "waarin de temporele activiteiten worden georkestreerd met beginpunten en eindes, opeenvolgingen, versnellingen en vertragingen, periodes van lange en korte duur, onderbrekingen et cetera." (Ibid., p. 23) Tijd als muziek. Misschien is het geen toeval dat een van de belangrijkste kunstfilosofen van de 20e eeuw, Susanne K. Langer, muziek als uitgangspunt neemt om uit te leggen hoe kunst menselijk gevoel kan symboliseren? Volgens Langer worden gewaarwordingen, gevoelens en emoties beleefd als complexe en dynamische patronen van spanning en ontspanning, verwachting en vervulling of uitstel en frustratie, en worden die patronen het meest duidelijk gearticuleerd in de muziek, met name in ritmiek (Langer 1953). Ook film, hebben we net gezien, kan gelaagde dynamische structuren verbeelden. The Dialogue Remains zou je kunnen bekijken als een mini-tijdschapje; een patroon van twee temporele ervaringen en mogelijk een derde, dat de andere twee tegelijk meebeleeft en observeert. Je kunt je afvragen of het om ervaringen van twee personages gaat of om de gespleten ervaring van een enkel personage, maar in beide gevallen worden twee perspectieven uit elkaar getrokken en een derde gesuggereerd. Wat gebeurt er als tijd geen geheel vormt? Wat maakt de overgang mogelijk van het ene naar het andere perspectief? Wat gebeurt er als die perspectieven conflicteren?

Maar je zou een tijdsschap ook ruimtelijk kunnen voorstellen, als een soort archeologische vindplaats, waar resten van allerlei aard en afkomstig uit diverse historische periodes bijeenliggen. Als je met een archeologisch oog naar je eigen materiële omgeving kijkt, zoals archeoloog Laurent Olivier deed, ontdek je dat sommige onderdelen een hele lange geschiedenis hebben waarin ze heel langzaam zijn veranderd, terwijl andere nog maar kort bestaan en heel snel veranderen. Je kunt dus ook in veel verschillende periodes tegelijkertijd leven; in een negentiende-eeuwse wijk, gebouwd binnen Middeleeuwse stadswallen of op zeventiende-eeuwse poldergrond, in een twintigste-eeuws huis en met eenentwintigste-eeuwse kasten van IKEA. En de werkzaamheid van het oude is niet beperkt tot een tijdperk in het verleden: een Middeleeuws stratenplan heeft nog altijd gevolgen voor waar je wel en niet kunt parkeren. Olivier noemde dat de multi-temporaliteit van het heden (Lucas 2005, p. 37).

Die veeltijdigheid wordt voelbaar in The Rest of Now. De tentoonstelling is een vindplaats van resten die uit allerlei windstreken zijn aangespoeld, scherven geschiedenis en snippers van verhalen, elk met een eigen suggestie van tijd. Wat de tentoonstelling daardoor aan de orde stelt, is hoe geografisch verspreide 'tijdschappen' nauwer bij elkaar betrokken en in elkaar verwikkeld raken en elkaar daardoor veranderen. De economische tijdsrekening van de internationaal opererende bauxietproductie komt in contact - en conflict - met de locale religieuze tijdsrekening waarin een heilige berg eeuwig is of zou moeten zijn. Het heden is multi-temporeel op globale schaal - het nu van Calcutta en Orissa is verbonden met het nu van TrentinoZuid-Tirol, en elk van die 'nu's zit vol met 'toen', met restanten, residuen, of wat daar voor door moet gaan. De kanttekeningen die hier worden geplaatst bij neo-liberale vertogen over economische globalisering, modernisering en vooruitgang zijn niet 
nieuw of verrassend - al maakt dat ze niet minder actueel. Wat spannend is, is dat de tentoonstelling niet alleen expliciet vragen stelde maar ook met de verbeelding en de ervaring van de tijd speelde.

\section{De archeologie van een gebouw}

En dat vooral omdat de tentoonstellingsruimte zelf wordt opgevoerd als een soort archeologische rest: The Naked Garden van Reinhard Kropf en Siv Helene Stangeland traceerde de sporen van de schimmels in de muren, Stefano Bernardi's Close your eyes registreerde de echo's van de verbouwing, Jorge Otero-Pailos' The Ethics of Dust conserveerde op latex vellen het vervuilde stof dat werd 'gered' van een van de muren; voor The air between two women van Anawane Haloba en Francesca Grilli moeten we afdalen in de vervallen kelders van de fabriek. Op allerlei manieren wordt voelbaar gemaakt dat je je bevindt in een gebouw dat in de tijd verandert, dat een geschiedenis heeft en ook in de toekomst nog steeds zal blijven veranderen. Ook daardoor gaat er iets schuiven.

Net als film is een tentoonstelling een medium dat de ervaring van de toeschouwer op een bepaalde manier ensceneert. Een tentoonstelling is een statische verzameling van objecten die tezamen van een veelheid van tijden kunnen getuigen, maar alle in een verondersteld heden worden getoond. Het gebouw speelt daar meestal geen rol in, behalve als stabiele ondergrond of achtergrond die dat heden draagt en verduurzaamt. Als dan de vloeren en muren van de tentoonstelling zelf onderdeel van de tentoonstelling worden, sterker nog, in de tijd gaan bewegen doordat hun veranderlijkheid en vergankelijk worden benadrukt, brengt dat even je oriëntatie van slag. Vergelijk het met de duizeling die je voelt als je in een stilstaande trein zitten en de trein naast je ziet bewegen - je weet dan een moment lang niet of die trein vertrekt of jouw eigen trein. Er gaat even iets wankelen in de ordening der dingen, even blijkt de waarneming minder coherent dan je dacht. Als tijd in zoveel snelheden en op zoveel schalen in scene gezet kan worden, en als ook het kader waarbinnen al die verschillende tijden worden gepresenteerd, schuivende is, kunnen we dan nog wel van 'de' tijd spreken? Is tijd wel een geheel?

Er kan een parallel getrokken worden met de stelling van de Indiase historicus Dipesh Chakrabarty, die betoogt dat post-koloniale geschiedschrijving afstand moet nemen van het idee van een enkelvoudige, seculiere, lege en homogene tijd waarbinnen de geschiedenis zich zou afspelen en die andere soorten tijd als een soort container zou omvatten. Als je de geschiedenis van sociale en politieke moderniteit in Zuid Azië wilt schrijven, stelt hij, moet je vaak van het omgekeerde uitgaan: dat historische tijd geen integraal geheel is, maar "out of joint with itself" (Chakrabarty 2008/2000, p. 16). Tijd die ontwricht is ten opzichte van zichzelf, uit de pas loopt met zichzelf: ik kan me dat eigenlijk niet voorstellen. Het aardige is dat The Rest of Now - het product van drie postkoloniale, Zuid-aziatische kunstenaars - je het bijna fysiek laat voelen, maar dan in Europa. Als je weer buiten komt en naar de Dolomieten kijkt, proef je hoe de geschiedenis van de plek waar je staat uit het spoor van de vooruitgang is gelopen.

\section{Tijdelijkheid}


Inmiddels is The Rest of Now ook geschiedenis en terugkijkend kun je je afvragen of de tentoonstelling niet zelf deel is van het proces dat ze aan de kaak stelde. Is er een bedrijf dat een hogere omloopsnelheid kent dan de hedendaagse kunst waar, zoals Anna Tilroe in de laatste Metropolis $M$ kritisch vaststelde, "de marktregel [geldt] dat iets van gisteren nooit zo goed kan zijn als dat van vandaag"? (Tilroe 2010, p. 27) Die omloopsnelheid ligt niet alleen aan de invloed van het marktdenken maar ironisch genoeg ook aan een aspect van de hedendaagse kunst dat vanuit een anti-commerciële houding is ontstaan: de tijdelijkheid van veel kunstwerken.

$\mathrm{Nu}$ The Rest of Now voorbij is zullen veel van de installaties ontmanteld zijn, omdat ze alleen zin hadden in de context van de tentoonstelling. De schimmelsporen kunnen niet eens van de ene plek naar de andere worden getransporteerd: ze kunnen niet losgemaakt worden van de muur waarin ze zijn aangebracht. De latex vellen met stof kun je wel in een ander gebouw ophangen, maar dan verliezen ze hun betekenis, omdat het stof dan niet het stof van die specifieke plek is. De telefooncentrale kan al weer gemakkelijker verplaatst worden; maar de betekenis ervan zal veranderen als het niet langer van belang is dat de centrale zelf als residu in de verlaten fabriek is aangetroffen. Dit zijn 'site-specific' kunstwerken, kunstwerken die op een of andere manier verbonden zijn met de plek waarop ze zijn geïnstalleerd en met de gelegenheid waarvoor ze zijn gemaakt.

The Dialogue Remains is daarmee vergeleken een relatief duurzaam werk, omdat het noch qua inhoud, noch qua materiële vorm geheel en al afhankelijk is van het evenement of de specifieke locatie. Toch spelen beide een rol, wat je kunt illustreren aan de latere geschiedenis ervan. Zo is de installatie onlangs opnieuw op verschillende plaatsen in India vertoond in de context van het reizende politieke filmfestival Resistance Persistance. Op een foto op de website van het festival kunnen we de opstelling op 27 februari van dit jaar in de India International Club in New Delhi zien. De ambiance is totaal veranderd. Wat je in de IIC mist is de beslotenheid van de nis die de twee projecties omvatte, de betonnen vloer en muren en de ijzeren rail in de vloer, die zo'n mooie verbinding vormden tussen de bouwscènes op de video's en de tentoonstellingsruimte. Dat hoeft niet alleen maar een verlies te zijn: wellicht zijn er op de nieuwe locatie weer andere interessante omgevingselementen die zich met het werk verbinden. In een video-interview met Ranu Ghosh, een maand geleden op YouTube gepubliceerd ${ }^{2}$, zien we de twee schermen buiten in een tuin omgeven door een fontein en bomen. Het karakter van het interview maakt duidelijk dat er nog andere verschillen zijn dan puur ruimtelijke. Zowel de interviewer als de maakster spreken vooral over het werk als een documentaire. De Manifesta was een tentoonstelling voor hedendaagse kunst, Persistence Resistance is een festival voor politiek kritische documentaire films. De twee publieken zijn verschillend een daarmee ook de chemie tussen werk en toeschouwer: het Indiase publiek zal de installatie als een documentaire-in-andere-vorm bekijken en brengt een geheel ander arsenaal aan kennis, verwachtingen en waarderingen mee dan het Europese kunstpubliek dat de taal niet verstaat, de rituelen niet begrijpt, nooit eerder van Ushi naaimachines heeft gehoord en het werk vooral als installatie zal benaderen en beoordelen. Er is nog een ander verschil: in de maanden direct na de Manifesta heeft de geschiedenis niet stil gestaan. Na een aantal keren bedreigd en mishandeld te zijn, is Shambu Prasad Singh in december 2008 definitief uit zijn huis gezet en is het huis

\footnotetext{
${ }^{2}$ http://www.youtube.com/watch?v=q97w5rd6OCc
} 
afgebroken. Zodra je dat weet, kijk je weer anders naar de beelden dan daarvoor, toen de afloop nog onbekend was en er nog hoop was dat Singh de strijd zou kunnen winnen. Dat kun je als een verschil in momentum aanduiden; een verschil dat in terugblik overigens bij mij ook de vraag oproept of de metafoor extract/residu niet bevestigt wat ze zou moeten bestrijden.

\section{Kunst en media}

Zo'n zwerftocht, van de ene biënnale naar het andere festival, van het ene deel van de wereld naar het andere, in steeds wisselende gedaantes en onder steeds nieuwe geografische en historische omstandigheden, is heel gewoon voor een hedendaags kunstwerk. Hedendaagse kunst gaat niet alleen vaak over globalisering, met alles wat dat proces betekent voor onze noties van tijd en geschiedenis, ze is daar zelf onderdeel van. De globalisering van de kunstwereld is de laatste jaren onderwerp van diverse projecten, tentoonstellingen en onderzoekingen: ik noem bijvoorbeeld het boek World Art Studies van Kitty Zijlmans en Wilfried van Damme; het project Global Art \& The Museum (geïnitieerd door Peter Weibel en Hans Belting, Zentrum für Kunst und Medientechnologie Karlsruhe), Nicholas Bourriauds tentoonstelling Altermodern (Tate Triennial 2009) en het project Former West (BAK Utrecht). Mijn hunch is - en het is op dit moment vooral nog een hunch, een vermoeden of, netjes gezegd, een werkhypothese - dat je een verrassend inzicht in de dynamiek van culturele globaliseringsprocessen kan ontwikkelen als je focust op hoe kunstwerken die dynamiek teweegbrengen. Aan de ene kant, analoog aan wat we 'close reading' noemen, door een 'close looking' of nog beter: 'close doing' van hoe een kunstwerk een onderwerp als ongelijktijdigheid thematiseert - aan de andere kant door te volgen hoe het als praktijk, in zijn concrete levensloop ongelijktijdigheid incorporeert. Zo'n tweesporige werkwijze koppelt een (post)fenomenologisch-esthetische benadering van media en toeschouwerschap aan ideeën en methoden die zijn ontwikkeld in het techniekonderzoek (Van de Vall 2009a), zoals etnografie, en is verwant met die van de jonge Nederlandse traditie van de empirische filosofie.

Dat is nog uitermate abstract. Er zijn twee projecten die concrete invulling zullen geven aan het gebied van deze leerstoel Kunst en Media en die beide het vraagstuk van de tijdelijkheid en ongelijktijdigheid in hedendaagse kunst uitwerken:

In het project New strategies in the conservation of contemporary art ${ }^{3}$, een samenwerkingsproject tussen onderzoekers van Instituut Collectie Nederland, de Universiteit van Amsterdam en uit onze faculteit Vivian van Saaze en mijzelf, wordt empirisch onderzoek gedaan naar conserveringspraktijken in musea om licht te werpen op de theoretische vraag hoe om te gaan met tijdelijk en veranderlijkheid, en daarmee ook de ongelijktijdigheid, van het artistieke erfgoed van de toekomst (Van de Vall 2009b). Hoe leven veranderlijke en vergankelijke werken voort in de tijd? Als verhalen, foto's, videoregistraties, kisten met rekwisieten, formulieren met gegevens, teksten in catalogi, mythes, ansichtkaarten, herinneringen, ideeën, recensies en niet te vergeten YouTube filmpjes? Wat zijn de resten van de hedendaagse kunst? En moeten we die resten inderdaad als residuen opvatten, waar het waardevolle uit verdwenen is, of als gedaanteverwisselingen, opeenvolgende stadia in een biografie of

\footnotetext{
3 http://www.newstrategiesinconservation.nl/
} 
traject, die op eigen wijze en vaak in andere, al dan niet nieuwere media doorgaan ervaringen teweeg te brengen?

Het tweede project heeft als onderwerp globalisering, kunst en media. Ik onderzoek hoe de globalisering en digitalisering van het artistieke medialandschap gestalte krijgen in moderne en hedendaagse Indiase kunst. Naast het voorbeeld dat in deze oratie centraal stond heb ik inmiddels geschreven over modernisme en kosmopolitisme in de abstracte composities van Nasreen Mohamedi (Van de Vall 2010).

Verschillend als die twee projecten mogen lijken, ik hoop $\mathrm{u}$ in de afgelopen drie kwartier te hebben laten zien dat ze elkaar op alle mogelijke manieren raken en veronderstellen.

\section{Tenslotte}

Het is tijd voor mijn dankwoord. Dat is in de eerste plaats gericht aan het College van Bestuur en aan het bestuur van de Faculteit der Cultuur- en Maatschappijwetenschappen, die deze profileringsleerstoel in het leven hebben geroepen en mij de kans hebben gegeven dit vakgebied Kunst en Media in de komende jaren vorm te geven. Binnen de faculteit wil ik in het bijzonder Rein de Wilde bedanken die als decaan zijn schouders onder dat project heeft gezet en Wiel Kusters en Lies Wesseling die dat hebben gedaan als opeenvolgende voorzitters van de capgroep Letteren \& Kunst. Mijn dank voor dit grote vertrouwen; zo ook mijn dank aan de leden van het College van Toezicht dat deze leerstoel zal gaan begeleiden.

Ik werk net iets meer dan 17 jaar aan deze faculteit. In de tijd van schaarse banen zou ik hier nooit zijn aangenomen als ik niet uit een uitstekend nest was gekomen, de Filosofische Faculteit van de Universiteit van Amsterdam, en in mijn scriptiebegeleiders Maarten van Nierop en promotor Theo de Boer uitmuntende leraren had gehad, van wie ik bijvoorbeeld kon leren hoe je zowel aanstekelijk als gestructureerd moet schrijven. Wiel Kusters durfde het er op te wagen voor zijn vakgroep een filosoof aan te nemen in plaats van een kunsthistoricus: in alle jaren heb ik me door hem enorm gewaardeerd en gesteund gevoeld. Dat geldt ook voor mijn capgroep-genoten, waarvan ik vooral Jack Post wil noemen, die al die 17 jaar mijn compagnon is geweest in het bedenken en vormgeven aan het onderwijs in Visuele Cultuur en Media Cultuur.

Op onderzoeksgebied heb ik in al die jaren met verschillende collega's binnen en buiten de capgroep en de faculteit gewerkt en daar veel van geleerd: naast Jack Post zijn dat de onderzoekers van de Mediated Body groep, en vooral José van Dijck, Rob Zwijnenberg, Jo Wachelder, Bernike Pasveer en Jenny Slatman, de leden van het Digital Games project, in het bijzonder Maaike Lauwaert en Martijn Hendriks; de New Strategies groep en speciaal IJsbrand Hummelen en Vivian van Saaze; de leden van Media \& Aesthetics, met name Karin Wenz, Ike Kamphof en Verena Anker. Omgevingen die uitermate vormend waren voor mijn werk waren de redactie van het tijdschrift Krisis en het Nederlands Genootschap voor Esthetica. Ik heb enorm veel plezier beleefd en inspiratie ontleend aan de vele studenten die ik mocht begeleiden. Zonder de solide steun en het oplettende oog van Lilian Essers, Anja Servais en Ineke 
Stevens zou er geen blokboek fatsoenlijk uit mijn handen zijn gekomen en was ik allang verdronken in de duizend kleine dingen die het werk in onze bruisende maar complexe organisatie met zich meebrengt.

Ik ben blij en dankbaar zoveel van mijn vrienden en vriendinnen in de zaal te zien zitten en zoveel lieve familieleden. Moniek, Kees, Sem en Fritzi maken dat ik iedere week op het Cremerplein ook echt thuiskom. Als mijn vader nog had geleefd, zou hij stralend van trots op de voorste rij hebben gezeten. Hij is er niet meer, maar Anneke wel, en we zullen straks samen zijn onnavolgbare big smile gedenken. En heel speciaal wil ik Constance Eugenie van der Maesen bedanken, mijn moeder, die als onversaagd geëngageerde soziale Wissenschaftler een voorbeeld is geweest voor generaties politicologiestudenten en zo ook voor mij. Het lijkt mij gepast om dit plechtige verhaal vol goede voornemens af te sluiten met de wijze woorden waarmee zij zo vaak onze telefoongesprekken afrondt: "Weet je wat we doen? We zullen wel zien!".

Ik dank u voor uw aandacht.

\section{Literatuur}

BAK Utrecht (2009). Former West - a contemporary art research, education, publishing, and exhibition project (2008-2013). http://www.formerwest.org/.Laatst bezocht op 14 mei 2010.

Basar, Shumon (2008). Manifesta Diary, Part 2: Bolzano and Trento. Art Review. Posted by artreview.com on July 24, 2008 at 11:30am. http://www.artreview.com/profiles/blog/show?id=1474022\%3ABlogPost\%3A364436 Laatst bezocht op 14 mei 2010.

Bourriaud, Nicholas (ed.) (2009). Altermodern. Tate Triennial. London: Tate Publishing.

Chakrabarty, Dipesh (2008/2000). Provincializing Europe. Postcolonial Thought and Historical Difference. With a new preface by the author. Princeton \& Oxford:

Princeton University Press.

Corbetta, Caroline (2008). Manifesta 7. Domus 917, 126-130.

Currie, Nick (2008). The Post-Materialist / Industrial Art Spaces. Design August 28.

Drake, Cathryn (2008). Italian hours. Bolzano-Bozen, Italy 07.24.08 http://artforum.com/diary/id=20807. Laatst bezocht op 14 mei 2010.

Fowkes, Maja en Fowkes, Reuben (2008). Manifesta Reaches New Heights. EXINDEX 2008. http://www.translocal.org/reviewsindex.html. Laatst bezocht op 14 mei 2010.

GAM - Global Art and the Museum. http://www.globalartmuseum.de/site/home.

Laatst bezocht op 14 mei 2010.

Griffin, Jonathan (2008). Postcards From Manifesta. Frieze Magazine - Comment

Published on $17 / 07 / 08$.

http://www.frieze.com/comment/article/postcards_from_manifesta/ Laatst bezocht op 14 mei 2010.

Gronlund, Melissa (2008). Manifesta 7. Frieze Magazine Issue 117 September 2008. http://www.frieze.com/issue/review/manifesta_7/ Laatst bezocht op 14 mei 2010. Herbert, Martin (2008). Manifesta 7. Artforum (October) pp. 371-373. 
Huijer, Marli (2008). Je hebt meer tijd als je denkt. Intreerede De Haagse

Hogeschool.

Imomus (2008). I came so far for beauty. click opera - imomus

http://imomus.livejournal.com/394673.html. Laatst bezocht op 14 mei 2010.

Kant, Immanuel (2009). Kritiek van het oordeelsvermogen. Ten geleide, vertaling en annotaties van Jabik Veenbaas en Willem Visser. Amsterdam: Boom.

Langer, S.K. (1953). Feeling and Form. A Theory of Art Developed from Philosophy in a New Key, London: Routledge \& Kegan Paul.

Lapp, Axel (2008). Dialogue - Profile of Manifesta. Axis - the online resource for

contemporary art. http://www.axisweb.org/dlFULL.aspx?ESSAYID=145. Laatst

bezocht op 14 mei 2010.

Latour, Bruno (2004). How To Talk About the Body? The Normative Dimension of Science Studies. Body \& Society 10 (2-3), pp. 205-229.

Lucas, Gavin (2005). The Archeology of Time. London and New York: Routledge.

Polsinelli, Michael (2008) Manifesta 7. Flash Art (October) pp. 57-58.

Rabottini, Alessandro (2008) Manifesta 7. Modern Painters. October 1, 2008

http://www.artinfo.com/news/story/28904/manifesta-7/ Laatst bezocht op 14 mei

2010.

Raqs Media Collective (2008) The rest of now/ Il resto di ora/ Der Rest vom Jetzt. In Manifesta 7 Index. Milano: Silvano Editoriale, pp. 49-60.

Rosenau, Mirja und Burke, Marius (2008) Jenseits von Tiroler Speck und

Alpenglühen. Art Magazine 7/08 pp. 50-53.

Rosenmeyer, Aoife (2008). Aoife Rosenmeyer on Manifesta 7 Trentino. Saatchi

Online http://www.saatchi-

gallery.co.uk/blogon/art_news/aoife_rosenmeyer_on_manifesta_7_trentino/4809.

Laatst bezocht op 14 mei 2010.

Sneed, Gillian (2008). Manifesta 7: From Residue, Resurrection. NY ARTS: The

international guide to the art world. http://www.nyartsmagazine.com. Laatst bezocht

op 14 mei 2010.

Sobchack, Vivian (1992). The Address of the Eye. A Phenomenology of Film

Experience, Princeton: Princeton University Press.

Sobchack, Vivian (2005). Carnal Thoughts. Embodiment and Moving Image Culture, Berkeley, Los Angeles and London: University of California Press.

Spaid, Sue (2008). Manifesta 7. Art US.

http://www.thefreelibrary.com/Manifesta+7.-a0202254860. Laatst bezocht op 14 mei 2010.

Tilroe, Anna (2010) Wie trekt er aan de bel? Metropolis M. Tweemaandelijks tijdschrift over hedendaagse kunst. Vol. $30 \mathrm{nr} 2$ april/mei pp. 20-27.

van de Vall, Renée (2008) At the Edges of Vision. A Phenomenological Aesthetics of Contemporary Spectatorship. Aldershot (UK) and Burlington VT: Ashgate.

van de Vall, Renée (2009a) A penny for your thoughts. Brain-scans and the mediation of subjective embodiment. In R. van de Vall \& R. Zwijnenberg (eds.) The Body

Within: Art, Medicine and Visualisation Leiden: Brill.

van de Vall, Renée (2009b) Towards a Theory and Ethics for the Conservation of Contemporary Art. In Art d'aujourd'hui - patrimoine de demain. Conservation et restauration des oeuvres contemporaines. 13es journées d'études de la SFIIC. Paris: Institut national du patrimoine 24-26 juin 2009 pp. 51-56.

van de Vall, Renée (2010) Looking for Nasreen. In search of a cross-cultural and performative aesthetics. In Jos de Mul \& Renée van de Vall (eds.) Gimme Shelter. Global Discourses in Aesthetics. Proceedings of an international symposium, 
organized by the Dutch Aesthetic Federation and the International Association of Aesthetics.

Zijlmans, Kitty en Van Damme, Wilfred (eds.) (2008) World Art Studies: Exploring Concepts and Approaches. Amsterdam: Valiz.

Zonnenberg, Natalie (2008) Manifesta 7. Metropolis M. Tweemaandelijks tijdschrift over hedendaagse kunst Vol. $28 \mathrm{nr} .5$ oktober/november

http://www.metropolism.com/magazine/2008-no5/manifesta-7/ Laatst bezocht op 14 mei 2010. 